\title{
Can red cell distribution width be a new parameter for predicting higher CD34+ cell count in the harvest?
}

\section{Eritrosit dağılım aralığı üründeki daha yüksek CD34+ hücre sayısını öngördüren yeni bir parametre olabilir mi?}

\author{
Eren Gündüz ${ }^{1}$, Tuba Bulduk ${ }^{1}$, Hava Üsküdar Teke ${ }^{1}$, Ahmet Musmul ${ }^{2}$, Neslihan Andıç ${ }^{1}$ \\ ${ }^{1}$ Eskişehir Osmangazi Üniversitesi Tıp Fakültesi, İç Hastalıkları Anabilim Dalı Hematoloji Bilim Dalı, Eskişehir \\ ${ }^{2}$ Eskișehir Osmangazi Üniversitesi Tıp Fakültesi, Biyoistatistik Anabilim Dalı, Eskişehir
}

Dergiye Ulaşma Tarihi: 10.07.2017 Dergiye Kabul Tarihi: 29.10.2017 Doi: 10.5505/aot.2018.88942

\section{ÖZET}

GíRiş ve AMAÇ: Eritrosit dağılım aralığı (RDW) anemi ayırıcı tanısında kullanılan basit ve ucuz bir parametredir fakat diğer hastalıklarla ilişkisi giderek artan oranda bildirilmektedir. Transplantasyon pratiğinde en sık kullanılan hematopoietik kök hücre kaynağı periferik kandır ve kök hücre mobilizasyonunu etkileyen birçok faktör tanımlanmıştır. Çalışmamızda RDW ile üründeki CD34+ hücre sayısı araşında bir ilişki bulmayı amaçladık.

YÖNTEM ve GEREÇLER: Çalışmaya 50 hasta dahil edildi. Tanılar multipl miyelom $(\mathrm{n}=32)$, non Hodgkin lenfoma $(\mathrm{n}=9)$, Hodgkin lenfoma $(\mathrm{n}=6)$, primer amiloidoz $(\mathrm{n}=1)$, Waldenström makroglobulinemisi $(\mathrm{n}=1)$ ve germ hücreli testis tümörü $(n=1)$ idi. Mobilizasyon rejimleri siklofosfamid+granülosit koloni stimule edici faktör (G-CSF), tek başına G-CSF, etoposid+G-CSF ve kurtarma tedavisi+G-CSF şeklindeydi. RDW'nin üründeki CD34+ kök hücre sayısına etkisini değerlendirmek için 16 eşik değer alınarak hastalar 2 gruba ayrıldı.

BULGULAR: Periferik kan ve üründeki CD34+ hücre sayısı açısından 2 grup arasında istatistiksel olarak anlamlı farklı bulunmamasına rağmen RDW'si yüksek olan grupta sayılar daha düşüktü. RDW ile periferik kan ve üründeki CD34+ hücre sayısı arasında korelasyon saptanmadı.

TARTIŞMA ve SONUÇ: Bildiğimiz kadarıyla çalışmamız kanser hastalarında RDW ile kök hücre mobilizasyonu arasındaki ilişkiyi değerlendiren ilk çalışmadır. Sonuçlarımız kök hücre mobilizasyonunun RDW'nin anemi dışı kullanım alanlarından biri olabileceğini düşündürmüştür.

Anahtar Kelimeler: eritrosit dağılım aralı̆̆ı, mobilizasyon, hematopoietik kök hücreler

\begin{abstract}
INTRODUCTION: The red cell distribution width (RDW) is a simple and unexpensive parameter for differential diagnosis of anemias. However, the number of articles mentioning about the relationship between RDW and human disorders is increasing. In transplantation practice, peripheral blood is the most common source of hematopoietic stem cells and many factors affect the success of mobilization. In this study, we tried to find a relationship between increased RDW and CD34+ cell count in the harvest.

METHODS: Fifty patients were included in the study. Diagnosis were multiple myeloma ( $n=32)$, non Hodgkin lymphoma $(\mathrm{n}=9)$, Hodgkin lymphoma $(\mathrm{n}=6)$, primary amyloidosis $(\mathrm{n}=1)$, Waldenstrom's macroglobulinemia $(\mathrm{n}=1)$ and testicular carcinoma $(\mathrm{n}=1)$. Mobilization regimens were cyclophosphamide plus granulocyte colony stimulatig factor (G-CSF), G-CSF alone, etoposide plus G-CSF and salvage chemotherapy plus G-CSF. RDW was not correlated with peripheral blood CD34+ cell count and CD34+ cell count in the harvest. Above $16 \%$ was set as a cut-off for increased RDW and patients were divided into 2 groups.

RESULTS: Although peripheral blood CD34+ cell count and CD34+ cell count in the harvest were not different statistically between 2 groups, the numbers were lower in the increased RDW group. RDW was not correlated with peripheral blood CD34+ cell count and CD34+ cell count in the harvest in both groups.

DISCUSSION AND CONCLUSION: To our knowledge, this is the first study evaluating the relationship between RDW and stem cell mobilization in cancer patients. It seems reasonable to use RDW far beyond the differential diagnosis of anemias and stem cell mobilization can be a potential candidate.
\end{abstract}


Keywords: red cell distribution width, mobilization, hematopoietic stem cells

\section{INTRODUCTION}

The number of articles investigating the relationship between RDW and human disorders has exponentialy increased over the past decades. RDW has been investigated in a number of cardiovascular diseases and proposed as a predictive biomarker of poor outcomes (1-3). Increased RDW has been found associated with acute pulmonary embolism, deep vein thrombosis and chronic thromboembolic pulmonary hypertension (46). An association between increased RDW and low estimated glomerular filtration rate and high mortality has been shown in several studies (7-9). Malignant obstructive jaundice, acute and chronic hepatitis $\mathrm{B}$, non-alcoholic steatohepatitis and cirrhosis are some of the liver diseases found associated with increased RDW (10-12). Increased RDW was associated with complicated hospitalization and high mortality in community acquired pneumonia and presence of right ventricular failure in chronic obstructive pulmonary disease (13). RDW has also been found increased in various malignancies such as colorectal, breast, lung etc. (14-15). Prognostic significance of RDW in hematological malignancies is scarce (1617).

Hematopoietic stem cell transplantation is a potential curative therapy for various hematological malignancies and several factors affecting the results of hematopoietic stem cell mobilization are described. In this study, we tried to find a relationship between RDW and the stem cell count in the harvest.To our knowledge, increased RDW is associated with poor stem cell mobilization in patients with advanced chronic heart failure ${ }^{18}$ but there is no report about the effect of RDW to mobilization in malignant diseaeses.

\section{MATERIALS AND METHODS}

Fifty patients who underwent stem cell mobilization between March 2014 and October 2015 are included in the study. Mean age was $56.82 \pm 10$ years, $28(56 \%)$ patients were male and $22(44 \%)$ patients were female. Diagnosis were multiple myeloma $(n=32)$, non Hodgkin lymphoma ( $n=9)$, Hodgkin lymphoma $(n=6)$, primary amyloidosis $(\mathrm{n}=1)$, Waldenstrom's macroglobulinemia $(n=1)$ and testicular carcinoma $(\mathrm{n}=1)$. Mobilization regimens were cyclophosphamide $\left(4 \mathrm{~g} / \mathrm{m}^{2} /\right.$ day plus G-CSF 5 $\mathrm{mcg} / \mathrm{kg} /$ day in $35(70 \%)$ patients, G-CSF 10 $\mathrm{mcg} / \mathrm{kg} /$ day alone in $2(4 \%)$ patients, etoposide $600 \mathrm{mg} / \mathrm{m}^{2}$ plus G-CSF $5 \mathrm{mcg} / \mathrm{kg} /$ day in 2 (4\%) patients and salvage chemotherapy plus G-CSF $5 \mathrm{mcg} / \mathrm{kg} /$ day in $11(22 \%)$ patients. Five (10\%) patients had a history of radiotherapy. 20 (40\%) patients had comorbidities (hypertension, diabetes, asthma, chronic obstructive pulmonary disease, renal failure, coronary artery disease, hypothyroidism, prostat carcinoma, tonsil carcinoma, atrial fibrillation, fibromyalgia, irritable colon, cerebrovascular disease). Bone marrow infiltration for patients except myeloma was found in $6(35 \%)$ patients. Patients received mean $1.61 \pm 0.60$ lines and $4.94 \pm 2.60$ courses of chemotherapy. RDW was measured in blood samples collected in EDTA tubes which were analyzed with an automated hematology analyzer system (Coulter LH 750 Hematology Analyzer, CA, USA). Normal RDW values ranged between $11.80 \%$ and $14.30 \%$ according to our laboratory standards. Biochemical parameters were determined with standard procedures. All blood samples were collected on first day of apheresis or maximum 1-3 days before apheresis. Laboratory parameters are shown in Table 1. Stem cells were collected during mean $1.82 \pm 0.75$ days. Since it shows high anisocytosis (19), above $16 \%$ was set as a cutoff for increased RDW and patients were divided into 2 groups. The research protocol has been approved by local ethical committee and performed in accordance with the ethical standards laid down in the Declaration of Helsinki. All patients gave informed consent prior to their inclusion in the study.

\section{Statistics}

All data analyses were performed using commercially available software (PASW Statistics 22, SPSS, Inc., Chicago, IL; and SigmaStat 3.5, Systat Software, Inc., San Jose, CA). Continuous normally distributed 
variables were demonstrated using $\mathrm{n}$ (sample size) and mean and standard deviation, continuous non normally distributed and categorical variables using n (sample size) and median and 25th and 75th percentiles. Score variables between 2 groups were compared using the Mann-Whitney U test. Spearman correlation analysis was used to determine correlations among non-normally distributed variables. Chi-square analyses were used for categorical variables. $\mathrm{p}<0.05$ was accepted as statistically significant. All data analyses were performed using commercially available software (PASW Statistics 22, SPSS, Inc., Chicago, IL).

\section{RESULTS}

RDW was not correlated with peripheral blood CD34+ cell count $(\mathrm{r}=0.064, \mathrm{p}=0,750, \mathrm{n}=28)$ and CD34+ cell count in the harvest $(r=-0.14$, $\mathrm{p}=0,340, \mathrm{n}=50$ ). Other parameters previously reported to affect stem cell mobilization (age, weight, number of chemotherapy courses before mobilization, hemoglobin, white blood cell count, absolute neutrophil count, absolute lymphocyte count, platelet count, albumin, lactate dehydrogenase) were also evaluated.
Peripheral blood CD34+ cell count $(r=0.694$, $\mathrm{p}=0,001, \mathrm{n}=50)$ and the number of chemotherapy courses before mobilization $(\mathrm{r}=-0.451, \mathrm{p}=0,008, \mathrm{n}=28)$ were found as the only parameters that affect CD34+ cell count in the harvest. In order to investigate the effect of increased RDW on the CD34+ cell count in the harvest; above 16 was set as a cut-off for increased RDW and patients were divided into 2 groups. Sex, primary diagnosis, stage, bone marrow infiltration, mobilization regimen, chemotherapy courses, radiotherapy, comorbidities, number of leukapheresis days were not different between two groups. Comparison of laboratory parameters are shown in Table 2. Lactate dehydrogenase (LDH) was the only parameter different between 2 groups. It was found higher in the increased RDW group $(\mathrm{p}=0,005)$. Although peripheral blood CD34+ cell count and CD34+ cell count in the harvest were not different statistically between 2 groups, the numbers were lower in the increased RDW group. RDW was not correlated with peripheral blood CD34+ cell count and CD34+ cell count in the harvest in both groups.

Table 1: Laboratory Parameters

\begin{tabular}{|c|c|}
\hline Parameter & Mean value \pm S. D. \\
\hline Hemoglobin (g/dl) & $9.96 \pm 10.00$ \\
\hline White bloed sount $\left(\mathrm{x} 10^{9} / \mathrm{L}\right)$ & $9.61 \pm 6.98$ \\
\hline Absolute neutrophil sount (x10\%/L) & $7.16 \pm 6.78$ \\
\hline Absolute lvmphosyte sount (x109/L) & $0.62 \pm 0.51$ \\
\hline Platelet $\left(\times 10^{9} / \mathrm{L}\right)$ & $48.44 \pm 42.56$ \\
\hline Red cell distribution width (\%) & $15.88 \pm 2.39$ \\
\hline Albumin (mg/dl) & $3.71 \pm 0.42$ \\
\hline Lactat debydrogenase(IU/L) & $543.62 \pm 356$ \\
\hline Peripheral blood CD34+ sell count $(/ \mu l)$ & $48.81 \pm 55.47$ \\
\hline
\end{tabular}

S.D. : Standard deviation 
Table 2: Comparison of Laboratory Parameters for Increased and Normal Red Cell Distribution Width (RDW)

\begin{tabular}{|c|c|c|c|}
\hline Parameter & $\begin{array}{c}\text { Mean } \pm \text { S. D. } \\
(R D W<16) \\
n=26\end{array}$ & $\begin{array}{c}\text { Mean } \pm \text { S. D. } \\
(R D W \geq 16) \\
n=24\end{array}$ & $\mathbf{p}$ \\
\hline Hemoglobin $(\mathrm{g} / \mathrm{dl})$ & $10.12 \pm 1.38$ & $9.79 \pm 1.74$ & 0,236 \\
\hline $\begin{array}{l}\text { White blood count } \\
\left(\times 10^{9} / \mathrm{L}\right)\end{array}$ & $8.77 \pm 5.21$ & $10.52 \pm 8.52$ & 0,573 \\
\hline $\begin{array}{l}\text { Absolute neutrophil } \\
\text { count }\left(\mathbf{x} 10^{9} / \mathrm{L}\right)\end{array}$ & $6.52 \pm 5.48$ & $7.85 \pm 8.02$ & 0,587 \\
\hline $\begin{array}{l}\text { Absolute lypuphocyte } \\
\text { count }\left(\mathbf{x} 10^{9} / \mathrm{L}\right)\end{array}$ & $0.61 \pm 0.58$ & $0.62 \pm 0.43$ & 0,525 \\
\hline Platelet $\left(x 10^{8} / \mathrm{L}\right)$ & $43.5 \pm 36.69$ & $53.79 \pm 48.35$ & 0,547 \\
\hline Alburoin $(\mathrm{mg} / \mathrm{dl})$ & $3.82 \pm 0.45$ & $3.59 \pm 3.59$ & 0,058 \\
\hline $\begin{array}{l}\text { Lactat debydrogenase } \\
\text { (IU/L) }\end{array}$ & $421.35 \pm 226.61$ & $676.08 \pm 423.13$ & $0,005^{*}$ \\
\hline $\begin{array}{l}\text { Peripheral blood CD34+ } \\
\text { cell count }(/ \mu l)\end{array}$ & $\begin{array}{c}54.97 \pm 62.33 \\
(\mathrm{n}=17)\end{array}$ & $\begin{array}{c}39.28 \pm 43.90 \\
(\mathrm{n}=11)\end{array}$ & 0,437 \\
\hline $\begin{array}{l}\text { CD34+ cell count in the } \\
\text { harxest }\left(x 10^{6} / \mathrm{kg}\right)\end{array}$ & $10.48 \pm 5.94$ & $8.07 \pm 5.01$ & 0,080 \\
\hline
\end{tabular}

S.D. : Standart deviation

\section{DISCUSSION}

One of the leading technical issues in routine assessment of RDW is that the reference range is highly analyzer dependent and hampers the use of universal reference ranges. Besides pathological causes there are physiological determinants of increased RDW such as erythropoietin stimulation, ageing, black ethnicity, physical exercise and pregnancy (19). The only possible physiological determinant was age for our patients however it was not accepted as a physiological determinant of increased RDW because of the similarity between 2 groups (58 vs 55.60 , $\mathrm{p}>0.05)$. The relationship between RDW and gender appears contradictory across different epidemiological investigations ${ }^{19}$. Gender was not also a physiological determinant according to our results. Using different analyzers can be a issue but our results were completely obtained from the same analyzer.

An increased RDW mirrors a profound deregulation of erythrocyte homeostasis and survival, which may be caused by a variety of abnormalities such as shortening of telomeres length, oxidative stress, inflammation, erythrocyte fragmentation, poor nutritional status, hypertension, dyslipidemia and abnormality of erythropoietin function. All these conditions are important prognostic factors for severe morbidity and death (19). It could be valuable to assess the relationship between RDW and inflammatory markers, hypertension, dyslipidemia, nutritional status and/or erythrocyte fragmentation in a clinical study but we did not evaluate this point as a limitation of our study. On the other hand, Lippi et al (20) discovered that the relationship between high RDW and increased levels of inflammatory indicators including CRP and 
erythrocyte sedimentation rate is independent of other associated comorbidities.

Being a single center study with small patient size and retrospective patient enrollment are other limitations of our study.

In our study; sex, primary diagnosis, stage, bone marrow infiltration, mobilization regimen, chemotherapy courses, radiotherapy, comorbidities, number of leukapheresis days were not different between two groups. As a result we suggested that these paramaters did not affect stem cell colection and RDW affected the results independently although the difference was not found statistically significant.

Since it shows high anisocytosis above $16 \%$ was set as a cut-off for increased RDW in our study. To our knowledge \%16 is the highest cut off for increased RDW reported in literature. Some cut off values reported are $\geq 13.60 \%$ (20), $>14.50 \%$ (21) and $>13.75 \%$ (22). We hypothesized that setting above $16 \%$

\section{REFERENSES}

1. Fisher B, Anderson S, Bryant J, et al. Twenty-year follow-up of a randomized trial comparing total mastectomy, lumpectomy, and lumpectomy plus irradiation for the treatment of invasive breast cancer. N Engl J Med 2002;347:1233-41. PMID: 12393820

2. Ashkanani F, Sarkar T, Needham GC, et al. What is achieved by mammographic surveillance after breast conservation treatment for breast cancer? Am J Surg 2001;182:207-10. PMID: 11587678

3. Humphrey LL, Helfand M, Chan BK, Woolf SH. Breast cancer screening: a summary of the evidence for the U.S. Preventive Services Task Force. Ann Intern Med 2002;137:347-60. PMID: 12204020

4. Rosenberg RD, Yankaskas BC, Abraham LA, et al. Performance benchmarks for screening mammography. Radiology 2006;241:55-66. PMID: 16990671

5. National Cancer Institute. Cancer stat fact sheets, 1995-2001. Available at: seer. cancer.gov/statfacts/html/breast.html. Accessed August 2,2016.

6. Orel SG, Fowble BL, Solin LJ, Schultz DJ, Conant EF, Troupin RH. Breast cancer recurrence after lumpectomy and radiation therapy for early-stage disease: prognostic significance of detection method. Radiology 1993;188:189-94. PMID: 8511295

7. Lewis JL, Tartter PI. The value of mammography within 1 year of conservative surgery for breast cancer. Ann Surg Oncol 2012;19:3218-22. PMID: 22766990 as a cut off may change results of some previously reported studies.

Although peripheral blood CD34+ cell count and CD34+ cell count in the harvest were not different statistically between 2 groups, the numbers were lower in the increased RDW group. RDW was not correlated with peripheral blood CD34+ cell count and CD34+ cell count in the harvest in both groups. We think the difference can reach to statistical significance in larger studies.

To our knowledge, this is the first study evaluating the relationship between RDW and stem cell mobilization in cancer patients. Although it has not been definitely established whether increased RDW is a risk factor or an epiphenomenon of an underlying biological and metabolic imbalance, it seems reasonable to suggest using RDW far beyond the differential diagnosis of anemias. Stem cell mobilization can be a potential candidate in this era.

\section{Conflict of interest: None}

8. Recht A, Silen W, Schnitt SJ, et al. Time-course of local recurrence following conservative surgery and radiotherapy for early stage breast cancer. Int J Radiat Oncol Biol Phys 1988;15:255-61. PMID: 2841261

9. Orel SG, Troupin RH, Patterson EA, Fowble BL. Breast cancer recurrence after lumpectomy and irradiation: role of mammography in detection. Radiology 1992;183:201-6. PMID: 1312733

10. Stomper PC, Recht A, Berenberg AL, Jochelson MS, Harris JR. Mammographic detection of recurrent cancer in the irradiated breast. AJR Am J Roentgenol 1987;148:39-43. PMID: 3491522

11. Hymas RV, Gaffney DK, Parkinson BT, Belnap TW, Sause WT. Is short-interval mammography necessary after breast conservation surgery and radiation treatment in breast cancer patients? Int $\mathrm{J}$ Radiat Oncol Biol Phys 2012;83:519-24. PMID: 22245193.

12. Khatcheressian JL, Hurley P, Bantug E, et al. Breast Cancer Follow-Up and Management After Primary Treatment: American Society of Clinical Oncology Clinical Practice Guideline Update. J Clin Oncol 2013;31:961-5. PMID: 23129741

13. Bevers TB, Anderson BO, Bonaccio E, et al. National Comprehensive Cancer Network. NCCN clinical practice guidelines in oncology: breast cancer screening and diagnosis. J Natl Compr Canc Netw 2009;7:1060-96. PMID: 19930975

14. Hassell PR, Olivotto IA, Mueller HA, Kingston GW, Basco VE. Early breast cancer: detection of recurrence after conservative surgery and radiation therapy. Radiology 1990;176:731-5. PMID: 2167500

Adress for correspondence: Eskişehir Osmangazi Üniversitesi Tıp Fakültesi İç Hastalıkları Anabilim Dalı Hematoloji Bilimdalı Meşelik 26480 Eskişehir Eskişehir - Türkiye

e-mail: egunduz@ogu.edu.tr

Available at www.actaoncologicaturcica.com

Copyright $\odot$ Ankara Onkoloji Hastanesi 
15. Arasu VA, Joe BN, Lvoff NM, et al. Benefit of semiannual ipsilateral mammographic surveillance following breast conservation therapy. Radiology 2012;264:371-7. PMID: 22692036

16. Grunfeld E, Dhesy-Thind S, Levine M. Clinical practice guidelines for the care and treatment of breast cancer:follow-up after treatment for breast cancer. CMAJ 2005;172:1319-20. PMID: 15883407

17. Dershaw DD. Mammography in patients with breast cancer treated by breast conservation (lumpectomy with or without radiation). AJR Am J Roentgenol 1995;164:309-16. PMID: 7839960

18. Dershaw DD, Shank B, Reisinger S. Mammographic findings after breast cancer treatment with local excision and definitive irradiation. Radiology 1987;164:455-61. PMID: 3037592

19. Buckley JH, Roebuck EJ. Mammographic changes following radiotherapy. Br J Radiol 1986;59:337-44. PMID: 3697610

20. McNaul D, Darke M, Garg M, Dale P. An evaluation of post-lumpectomy recurrence rates: Is follow-up every 6 months for 2 years needed? J Surg Oncol 2013;107:597-601. PMID: 23280430
21. Lin K, Eradat J, Mehta NH,et al. Is a short-interval postradiation mammogram necessary after conservative surgery and radiation in breast cancer? Int J Radiat Oncol Biol Phys 2008;72:1041-7.PMID: 18407428

22. Sharp PC, Michielutte R, Freimanis R, Cunningham L, Spangler J, Burnette V. Reported pain following mammography screening. Arch Intern Med 2003;163:833-6. PMID: 12695274

23. Bugbee ME, Wellisch DK, Arnott IM, et al. Breast core-needle biopsy: clinical trial of relaxation technique versus medication versus no intervention for anxiety reduction. Radiology. 2005;234:73-8. PMID: 15564386

24. Maxwell JR, Bugbee D, Wellisch DK, Shalom A, Sayre J, Bassett LW. Image- guided core needle biopsy of the breast: Study of psychological outcomes. Breast J 2000;6:53-61. PMID: 11348335

25. Mertz KR, Baddour LM, Bell JL, Gwin JL. Breast cellulitis following breast conservation therapy: a novel complication of medical progress. Clin Infect Dis 1998;26:481-6. PMID: 9502474 